\title{
A Revised Storie Index for Use with Digital Soils Information
}

ANTHONY TOBY O'GeEN, Cooperative Extension Soil Resource Specialist, Department of Land, Air, and Water Resources, University of California, Davis; SUSAN B. SOUTHARD, USDA Natural Resources Conservation Service, Davis; and RANDAL J. SOUTHARD, Professor of Soil Science, Department of Land, Air, and Water Resources, University of California, Davis

The Storie Index is a widely known and accepted method of rating soils for land use and productivity in California. This soil-based land classification system has been used in California for over 50 years. Storie ratings can be found in published soil surveys throughout California. The latest version of the Storie Index was published in 1978 (Storie 1978). Traditionally, Storie Index ratings have been hand generated by soil survey staff and collaborators. These ratings can be highly subjective because no single person has generated Storie ratings for the entire state, and because of the inherent biases associated with the design of the classification system. We have developed a revised version of the Storie Index that generates ratings digitally from the USDA Natural Resources Conservation Service (NRCS) National Soil Information System (NASIS). This revised Storie Index is generated from a wide range of soil profile and landscape characteristics similar to those in the Storie 1978.

Since 2005, the NRCS has published Storie Index ratings generated by our revised Storie Index method, which will reduce the subjectivity associated with this form of land classification. The revised model is well correlated with statewide trends in hand-generated Storie ratings (O'Geen and Southard 2005). The purpose of this publication is to document our approach in converting Storie 1978 into the revised Storie Index modeled in NASIS. As such, this publication will serve as an official source of metadata for soil survey users, USDA NRCS technical service providers, and the National Cooperative Soil Survey (NCSS).

\section{BACKGROUND}

The Storie Index is a semiquantitative method of rating soils used mainly for irrigated agriculture based on crop productivity data collected from major California soils in the 1920s and 1930s (Storie 1932; Reganold and Singer 1979). The Storie Index assesses the productivity of a soil from the following four characteristics: Factor A, the degree of soil profile development; Factor B, surface texture; Factor C, slope; and Factor X, other soil and landscape conditions including the subfactors drainage, alkalinity, fertility, acidity, erosion, and microrelief. A score ranging from 0 to $100 \%$ is determined for each factor, and the scores are then multiplied together to generate an index rating (Storie 1978).

One shortcoming of hand-generated Storie ratings is that the scoring options for a particular factor or subfactor have broad and somewhat arbitrary ranges, which creates a great potential for subjectivity among scientists (O'Geen and Southard 2005). Our goal was to develop a model in NASIS to rapidly generate Storie ratings without inherent scoring discrepancies associated with hand-generated ratings.

Storie Index rating $=[($ Factor $A / 100) \times($ Factor $B / 100) \times($ Factor $C / 100) \times($ Factor $X / 100)] \times 100$ 


\section{Factor A: Soil Profile Group}

Factor $\mathrm{A}$ is a rating of the character of the soil profile based on the degree of soil development. Soils are placed in "profile groups" based on landform type and genetic horizon development. Soil development is defined as the presence of Bt horizons or cemented layers. Bt horizons are subsurface layers that have an increase in clay relative to the overlaying horizons. The increase is a result of the translocation of clay by percolating water from overlaying soil horizons.

For alluvial soils, the score is progressively decreased with increasing degree of soil development, as indicated by the presence of Bt horizons and/or the presence of root restrictive layers. For example, deep, homogeneous alluvial soils are rated $100 \%$, whereas soils with Bt horizons on older landscapes are rated lower. Soils with abrupt textural changes (claypan), duripan, or petrocalcic horizons (hardpans) are rated lower still. For soils derived from bedrock, scoring is based on depth to a lithic (hard rock) or paralithic (soft rock) contact and the degree of soil development in horizons overlying these layers (Storie 1932, 1978).

\section{Factor B: Surface Texture}

Factor B is based on surface texture. Loamy soils receive the highest ratings, and clay-rich and sandy soils receive lower ratings. Rock fragment content is used to modify the scores, which range from 100 to $10 \%$. The rating for Factor B can vary as much as 30\% for a specific textural class depending on the volume of coarse fragments present (Storie 1932, 1978).

\section{Factor C: Slope}

Factor $\mathrm{C}$ is based on steepness of slope. Nearly level to gently sloping conditions ( 0 to $8 \%$ slope) receive high scores, which range from 100 to $85 \%$. Moderate to strongly sloping conditions (9 to $30 \%$ slopes) have scores ranging from 95 to $70 \%$; slopes greater than $30 \%$ receive lower scores, ranging from 50 to $5 \%$ (Storie 1978). Users choose a score in a somewhat subjective manner based on these slope classes.

\section{Factor X: Drainage, Alkalinity, Fertility, Acidity, Erosion, and Microrelief}

Factor $\mathrm{X}$ focuses on dynamic properties, soil and landscape conditions that require special management considerations. Characteristics considered are drainage class, alkalinity, nutrient status, degree of acidity, wind and water erosion, and microrelief. Scoring for each characteristic in Factor $\mathrm{X}$ is subjective. For example, drainage, erosion, and microrelief scores range from 100 to $10 \%$, while fertility status and acidity scores range from 100 to 60 and 95 to $80 \%$, respectively (Storie 1978).

\section{REVISED STORIE INDEX}

\section{Model Development}

In our NASIS-based Storie Index, interpretation criteria were modeled based on soil properties traditionally incorporated into the hand-generated Storie Index (1978). The most closely related NASIS data elements that pertained to the Storie 1978 criteria were used. Our model uses discrete and fuzzy logic functions to obtain more precise scores for the factors associated with the index. Many of these criteria were incorporated in our model, and other factors were modified to adapt the index to a relational database. Adaptations that changed the Storie 1978 model are discussed in the applicable sections below.

The USDA NRCS developed NASIS, a comprehensive software tool, to manage soil survey data in a relational database. The software supports both soil mapping and the dissemination of soil survey information. An interpretation generator in NASIS allows custom interpretations to be developed that can be applied to soils within a map unit. The interpretation output either can have discrete, "crisp" limits (i.e., Boolean statements "true" or "false") or can reflect the concept of fractional truths (fuzzy membership) documenting the continuum among truth values between "completely true" and "completely false." Fuzzy logic concepts have been found to be very pertinent to the distribution of soil properties on the landscape and to resulting soil interpretations (Cox 1999). A system of interpretation generation using fuzzy logic was included within the database structure during NASIS development in order to develop more realistic soil interpretations. Our model uses fuzzy rule sets to more accurately score Factors C and $\mathrm{X}$. Discrete numerical scores in combination with fuzzy logic functions were used for Factors A and $\mathrm{B}$. The structural organization of the NASIS Storie model is summarized in figure 1. Gelisols, Histosols, Spodosols, Oxisols, and Andisols were not rated because these soils were not addressed in Storie 1978.

\section{Factor A: Soil Profile Group}

The number of soil profile groups for Factor A was changed from nine in Storie 1978 to a total of four (see fig. 1). The Storie 1978 profile groups classify 
Figure 1. Outline of the Storie Index applied to NASIS.

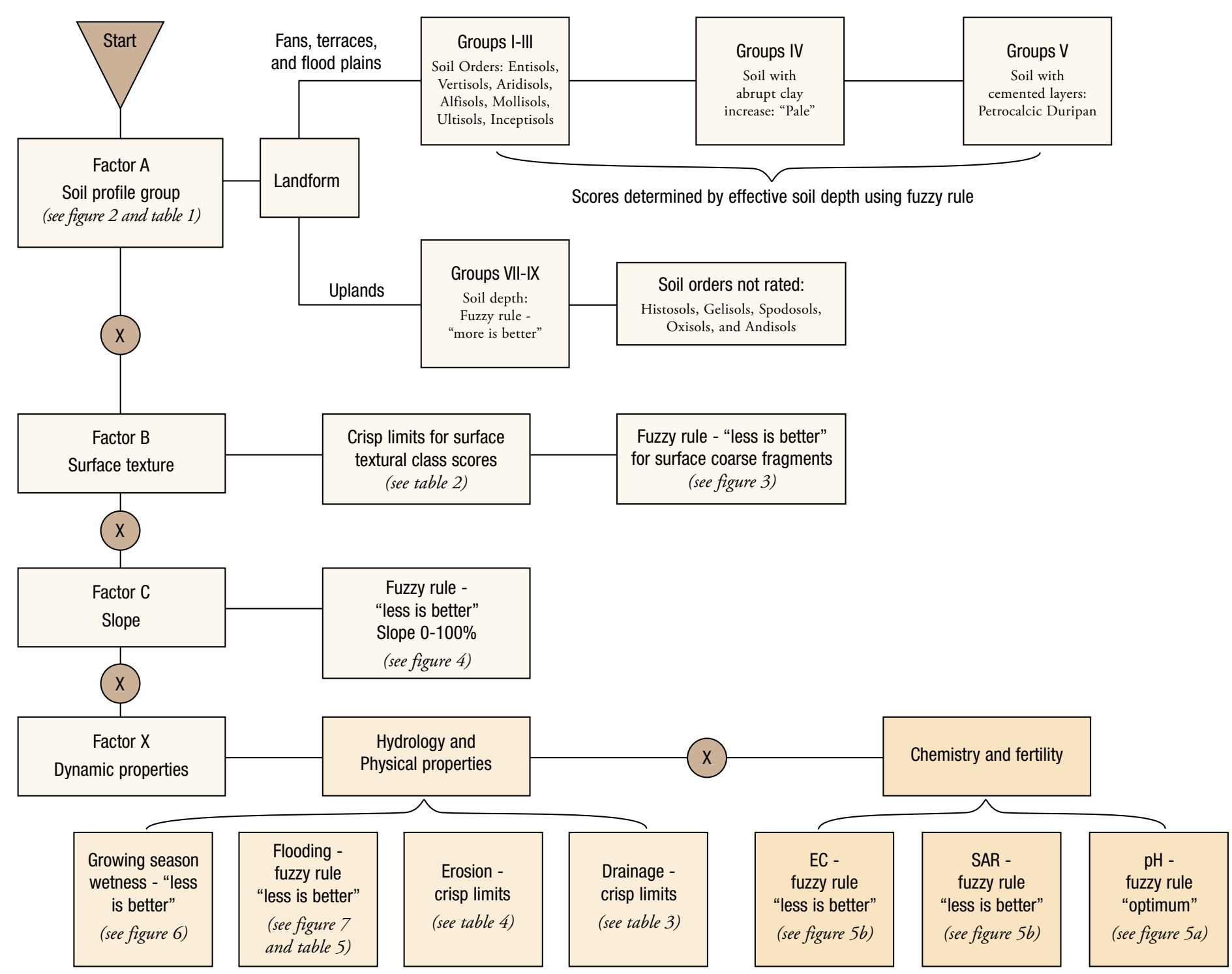

soils based on their degree of development and the nature of the parent material. Our model differs from that approach by combining profile groups where the scoring range among groups was similar. Interpretive criteria implied in Storie Profile Group Factor A relied on the current taxonomic placement (USDA NRCS 1999) of the soil in NASIS. Thus, in some instances, out-of-date classifications needed to be considered (table 1). Variations on the profile group fuzzy rating curves (slope and shape) that modify the effective rooting depth were devised to best match the original scoring in Storie 1978 (figs. 2A-2D).

The first step in the modeling process was to separate soils derived from bedrock (Groups VI to IX) from those forming in alluvium (Groups I to V). Landform type, a data field stored in NASIS, was used for this initial classification.
Groups I to III of Storie 1978 were combined because they have a similar scoring range and reflect subtle differences in soil development. These soils, which are found on alluvial deposits, are scored based on the depth to root-restricting layers such as shallow phases, consolidated material, gravel lenses, and stratified layers with texture contrasts. The scoring differences are identical in Groups I and II of Storie 1978 and are only slightly lower in Group III. For these reasons they were combined in our model. The soils of Groups I to III were identified through their classification. In general, all Entisols, Inceptisols, Vertisols, Aridisols, Alfisols, Mollisols, and Ultisols without an abrupt increase in clay with depth or a cemented layer were included. A "more is better" fuzzy rating was applied to these profiles in reference to depth to a restrictive layer. The curve reflects an 
Table 1. Factor A, the designation of soil profile groups* through taxonomic data stored in NASIS

\begin{tabular}{|c|c|c|c|}
\hline $\begin{array}{l}\text { Storie } 1978 \\
\text { proffle } \\
\text { group }\end{array}$ & $\begin{array}{l}\text { Revised } \\
\text { proffle } \\
\text { group }\end{array}$ & Taxonomic units queried & $\begin{array}{l}\text { Concept notes and } \\
\text { query rules }\end{array}$ \\
\hline I & 1 & $\begin{array}{l}\text { Suborders: Fluvents, Aquents, Psamments, Orthents, Xererts, Torrerts, Usterts, Uderts } \\
\text { Great groups: Haplaquolls, Aquisalids, Calciaquerts, Dystraquerts, Epiaquerts } \\
\text { Endoaquerts, Natraquerts, Salaquerts } \\
\text { Subgroups: Calcic Haplosalids, Gypsic Haplosalids, Typic Haplosalids }\end{array}$ & $\begin{array}{l}\text { Soils of recent alluvial deposits. } \\
\text { Query rules: Must not have } \\
\text { restrictive horizons and cannot } \\
\text { be on hillslopes or mountains. }\end{array}$ \\
\hline II & 1 & $\begin{array}{l}\text { Suborders: Arents, Cambids } \\
\text { Great groups: Haploxerolls, Haplustolls, Hapludolls, Vermustolls, Calciustolls, } \\
\text { Haprendolls, Calciudolls, Vermudolls, Calciaquolls, Calcigypsids, Haplogypsids, } \\
\text { Haplocalcids, Sulfaquepts, Vermaquepts, Endoaquepts, Epiaquepts, Humaquepts, } \\
\text { Sulfudepts, Eutrudepts, Dystrudepts, Calciustepts, Dystrustepts, Haplustepts, } \\
\text { Calcixerepts, Haploxerepts } \\
\text { Outdated taxa: Xerumbrepts and Xerochrepts }\end{array}$ & $\begin{array}{l}\text { Young soils on alluvial } \\
\text { deposits. Query rules: Cannot } \\
\text { be on hillslopes or mountains. } \\
\text { Outdated taxa included if updates } \\
\text { were not performed in NASIS. } \\
\text { Presence of abrupt textural } \\
\text { change included for stratified } \\
\text { soils and gravelly subsoils. }\end{array}$ \\
\hline III & 1 & $\begin{array}{l}\text { Great groups: Argigypsids, Natrigypsids, Natrargids, Gypsiargids, Calciargids, } \\
\text { Haplargids, Vermaqualfs, Epiaqualfs, Endoaqualfs, Glossaqualfs, Kandiaqualfs, } \\
\text { Natraqualfs, Hapudalfs, Kandiudalfs, Kanhapludalfs, Natrudalfs, Haplustalfs, Rhodustalfs, } \\
\text { Natrustalfs, Natrixeralfs, Rhodoxeralfs, Haploxeralfs, Argialbolls, Natralbolls, Natraquolls, } \\
\text { Argiaquolls, Natrudolls, Argiudolls, Natrustolls, Argiustolls, Natrixerolls, Argixerolls, } \\
\text { Kandiaquults, Kanhaplaquults, Umbraquults, Endoaquults, Epiaquults, Kandihumults, } \\
\text { Kanhaplohumults, Haplohumults, Kandiudults, Kanhapludults, Hapludults, Rhodudults, } \\
\text { Kandiustults, Kanhapustults, Rhodustults, Haplustults, Haploxerults; also includes all } \\
\text { "pale" great groups and Albaqualfs and Albaquults that do not have an abrupt clay } \\
\text { increase with depth, but may have a thick argillic }\end{array}$ & $\begin{array}{l}\text { Moderately well-developed soils } \\
\text { formed in older alluvial deposits. } \\
\text { Query rules: Cannot be on } \\
\text { hillslopes or mountains. Presence } \\
\text { of abrupt textural change } \\
\text { included for stratified soils and } \\
\text { gravelly subsoils. }\end{array}$ \\
\hline IV & 2 & $\begin{array}{l}\text { Great groups: All "pale" great groups of Aridisols, Mollisols and Alfisols, and } \\
\text { Albaqualfs and Albaquults that also have abrupt clay increase with depth }\end{array}$ & $\begin{array}{l}\text { Strongly developed soils formed } \\
\text { in old alluvial deposits. Query } \\
\text { rules: Cannot be on hillslopes or } \\
\text { mountains. }\end{array}$ \\
\hline $\mathrm{V}$ & 3 & $\begin{array}{l}\text { Suborder: Durids } \\
\text { Great groups: Petro, Dur, Fragi, Petra, Plinth } \\
\text { Subgroups: Duric Haplosalids, Petrogypsic Haplosalids } \\
\text { Other: Calciudolls that have a petrocalcic horizon }\end{array}$ & $\begin{array}{l}\text { Soils with hardpans formed } \\
\text { in old alluvial deposits. Query } \\
\text { rules: Cannot be on hillslopes } \\
\text { or mountains. Fuzzy rule depth } \\
\text { to restrictive horizon used to } \\
\text { generate score. }\end{array}$ \\
\hline VI & 2 & Not included & $\begin{array}{l}\text { Group VI was dropped because } \\
\text { of its similarity to Group IV. }\end{array}$ \\
\hline VII-IX & 4 & All colluvial and residual soils formed on mountains and hillslopes & $\begin{array}{l}\text { Groups VII to IX were combined } \\
\text { based on soil depth in Storie } \\
1978 \text { to bedrock or consolidated } \\
\text { material. Soils on upland areas. } \\
\text { Fuzzy rule depth to lithic or } \\
\text { paralithic contact used to } \\
\text { generate score. }\end{array}$ \\
\hline
\end{tabular}

Note: *Landform type, a field stored in NASIS, was first used to separate alluvial soils (Groups I to V) from upland soils (Groups VI to IX). Soil Taxonomy (USDA NRCS 1999) was used to place the soil in one of four new groups. Histosols (peat soils), Gelisols (soils with permafrost), Oxisols (highly weathered tropical soils), Andisols (volcanic soils), and Spodosols (cool humid forest soils) were not rated. 
Figure 2. Fuzzy logic rating functions "more is better" to define the effective soil depth in Factor A, soil profile group. A: A rating curve for Profile Groups I-III. B: A rating curve for Profile Group IV describing the depth to an abrupt texture change. C: A rating curve for Profile Group V depth to a cemented pan. D: A rating curve for Profile Groups VII-IX describing the depth to bedrock.
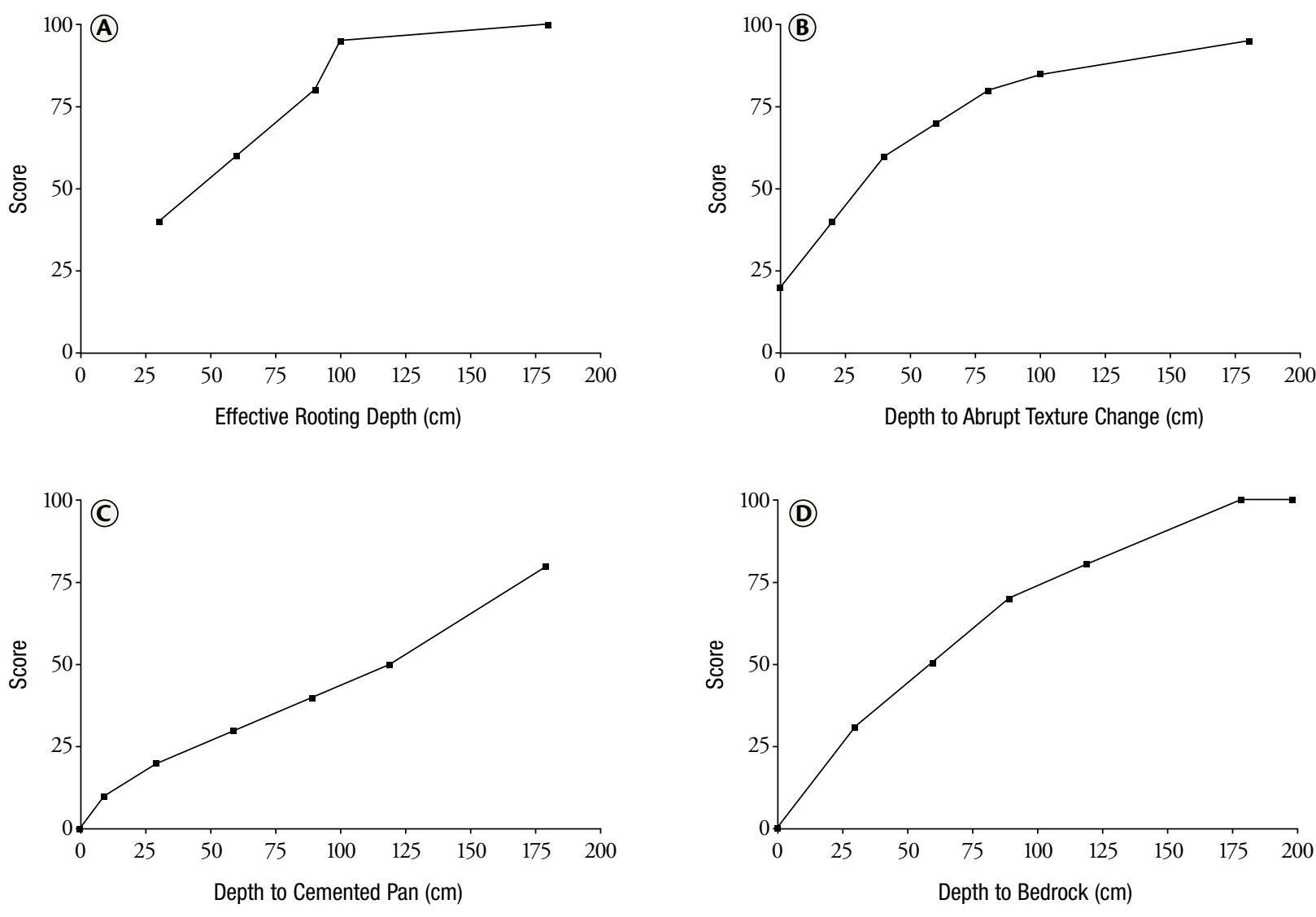

optimal effective rooting depth where soil thicknesses that exceed 100 centimeters received a maximum score of 100 (see table 1 and fig. 2A). Scores were reduced based on depth to root-restrictive layers mentioned above, which are flagged in NASIS.

The original concept of Profile Group IV in Storie 1978 was maintained in our model. Soils in this group are found on older plains and terraces and have dense, clay-rich subsoils that restrict the movement of water and roots. Soils in this group were identified in NASIS based on Soil Taxonomy (USDA NRCS 1999). All soils with the formative element "pale" at the great group level were included. In addition, Albaqualfs and Albaquults were included. The upper limit of the scoring range for Profile Group IV in Storie 1978 was initially assigned, then modified by effective soil depth. For example, a Palexeralf (a soil with a claypan) with depth to a claypan of less than 1 foot would initially receive a score of 85 . A fuzzy logic rule "more is better" in reference to depth to claypan was used to revise the upper limit of the score based on the exact depth (the representative value for depth in NASIS) to the restrictive horizon (see fig. 2B). This results in a much lower Factor A rating for the Palexeralf ( 35) based on the thickness of soil above the clay-rich layer.

The original concept of Group V was maintained in our model. Soils in this group are found on older fans and terraces and have dense, cemented subsoils that restrict the movement of water and roots. All soils with the formative elements Duri, Petro, Fragi, Petra, and Plinth that appear at the great group level were included. In addition, all Durids classified at the suborder level and Duric or Petrogypsic at the subgroup level were included. The upper limit of the scoring range for Profile Group V in Storie 1978 was initially assigned. A fuzzy logic rule "more is better," in reference to depth to the cemented pan, was then used to revise the upper limit of the score based on the exact depth (the representative value for depth in NASIS) to the restrictive horizon (see fig. 2C). 
Table 2. "Crisp" rating scores for Factor B, surface horizon textural class

\begin{tabular}{|l|c|}
\hline Surface textural class & Rating \\
\hline very fine sandy loam, fine sandy loam, loam, silt, silt loam & 100 \\
\hline $\begin{array}{l}\text { loamy very fine sand, sandy loam, sandy clay loam, } \\
\text { calcareous silty clay loam, clay loam }\end{array}$ & 95 \\
\hline $\begin{array}{l}\text { coarse sandy loam, loamy fine sand, noncalcareous silty } \\
\text { clay loam, clay loam }\end{array}$ & 90 \\
\hline loamy sand, very fine sand & 80 \\
\hline fine sand, loamy coarse sand, sandy clay & 65 \\
\hline sand, silty clay & 60 \\
\hline clay & 50 \\
\hline coarse sand & 30 \\
\hline
\end{tabular}

Figure 3. "Less is better" fuzzy rating curve for Factor B, surface rock fragment content. Straight line segments represent three classes of rock fragment volume percent populated in NASIS: $0-15,15-35$ and $\geq 35$.

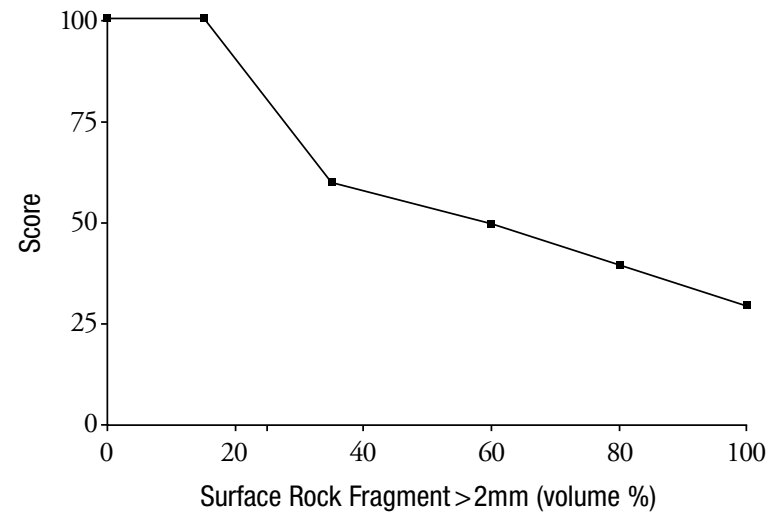

Figure 4. "Less is better" fuzzy rating curve for Factor C, slope. Most soil scientists express slope gradient as a percent, the difference in elevation between two points as a percentage of the distance between those points. Slopes of $100 \%$ are equivalent to a $45^{\circ}$ slope angle.

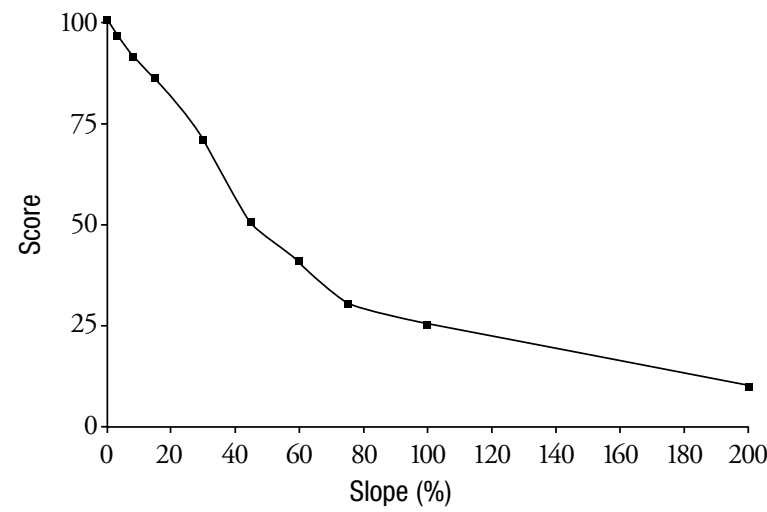

Formative elements of restrictive horizons are not used at the great group level in Soil Taxonomy (1999) where the upper boundary of the layer is greater than 1 meter below the surface. In such cases, the depth to these layers is populated in NASIS as a component restriction in the database. A "flag" was placed in the model so that when the component restriction attribute is populated the soil is placed in its appropriate profile group and scored accordingly.

Group VI in Storie 1978 was dropped because of its similarity in concept and scoring to that of Group IV.

Groups VII to IX in Storie 1978 were combined because they have a similar scoring range based on rooting depth and because the lithology of bedrock is not always populated in NASIS. This group reflects soils with residuum and colluvium as the parent material. The fuzzy logic rule "more is better," in reference to depth to lithic or paralithic contact, was used to modify the score based on the rooting depth (see table 1 and fig. 2D).

\section{Factor B: Surface Texture}

Crisp values were assigned for surface horizon textural classes according to Storie 1978 (table 2). The following textures were not listed in Storie 1978: very fine sandy loam, sandy clay, loamy coarse sand, loamy fine sand, loamy very fine sand, and silt. These missing textural classes were assigned ratings in our model (see table 2). At the present time, the NASIS model does not rank organic horizons.

All textural class ratings were modified based on rock fragment content using the general fuzzy logic rule "less is better" (fig. 3 ). The slope of line segments differed based on three coarse fragment volume classes: less than $15 \%, 15$ to $35 \%$, and greater than or equal to $35 \%$. The fuzzy score for rock fragment content was then used to weight the surface soil textural class score for Factor B. For example, a silt loam with $5 \%$ rock fragments received a score of $100 \%$, while a very gravelly silt loam with $40 \%$ rock fragments received a score of approximately $60 \%$, that is, it was weighted proportionally to the volume of coarse fragments present.

\section{Factor C: Slope}

The scoring threshold values for slope classes established in Storie 1978 were used to append the fuzzy logic rule "less is better" to produce a unique score for any representative value of slope stored in NASIS (fig. 4). This function reduced the subjectivity associated with choosing a score from the range of scores within each factor. For example, Storie 1978 
Figure 5A. "Optimal" fuzzy rating curve for Factor $\mathrm{X}, \mathrm{pH}$, in the surface layer. Optimal values are between $\mathrm{pH} 5.5$ and 8.5. Only extremes in $\mathrm{pH}$ resulted in lower scores.

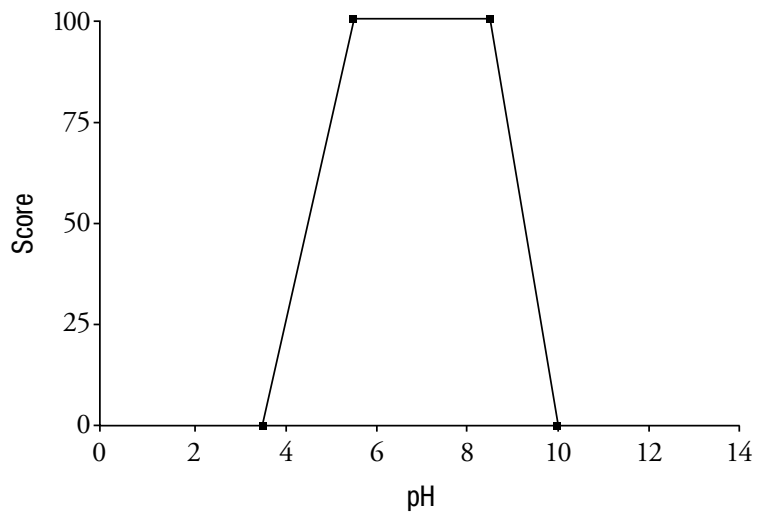

Figure 5B. "Optimal: less is better" fuzzy rating curve for Factor $X$ surface soil sodium adsorption ratio. Scores become lower when SAR values exceed 7 .

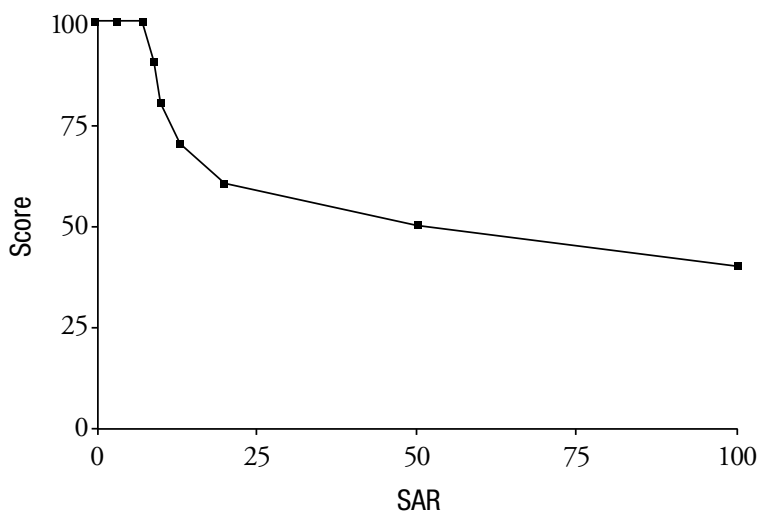

Figure 5C. "Optimal: less is better" fuzzy rating curve for Factor $X$, surface soil electrical conductivity (EC). Scores become lower when EC values exceed 1.0.

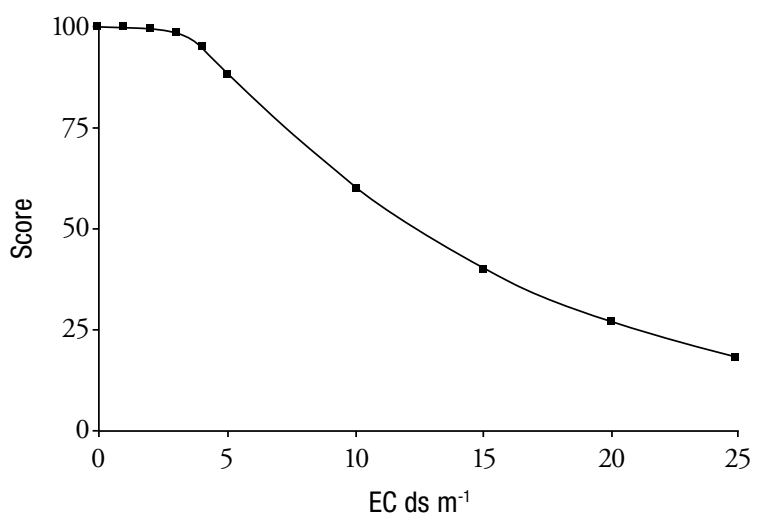

Factor C (slope) has slope categories with scores that range from $100 \%$ ("nearly level") to 5\% ("very steep"). Figure 4 is an example of the fuzzy logic function used to assign a unique score for the representative slope value of a soil map unit stored in NASIS.

\section{Factor X: Dynamic Properties}

Data elements stored in NASIS that pertain to Factor $\mathrm{X}$ (renamed "Dynamic Properties" in our model) were combined into two groups: chemical and fertility properties $\left(\mathrm{X}_{\mathrm{cf}}\right)$; and hydrologic and physical conditions $\left(\mathrm{X}_{\mathrm{hp}}\right)$.

Soil chemical and fertility limitations were established for $\mathrm{pH}$, electrical conductivity (EC), and sodium adsorption ratio (SAR). Hydrologic and physical conditions were assessed using drainage class, flooding frequency, flooding duration during the growing season, saturated conditions during the growing season, and erosion class. The Factor $\mathrm{X}$ score was calculated as the product of the lowest score in each subfactor group $\left(\mathrm{X}_{\mathrm{cf}}\right.$ and $\left.\mathrm{X}_{\mathrm{hp}}\right)$. Thus, in our model, only the two most limiting dynamic properties are used to calculate Factor X.

$\mathrm{X}_{\mathrm{cf}} \times \mathrm{X}_{\mathrm{hp}}=$ Factor $\mathrm{X}$

where:

$X_{c f}$ is the lowest chemical and fertility subfactor score

$\mathrm{X}_{\mathrm{hp}}$ is the lowest hydrologic and physical condition subfactor score

The chemical conditions of the revised Factor X differ slightly from Storie 1978, which used somewhat arbitrary classes for alkalinity, fertility level, and acidity. In order to obtain more quantitative indices for chemical conditions in soil, thresholds in toxicity or osmotic effects were established for electrical conductivity (EC) and $\mathrm{pH}$ to reflect conditions that adversely affect plant growth, as well as for sodium adsorption ratio (SAR) to reflect conditions that affect soil dispersion and water movement. Soils receive ratings of $100 \%$ until suboptimal levels are encountered. Fuzzy rule sets were implemented in NASIS to model the magnitude of the impairment. For example, an optimal curve was used to score $\mathrm{pH}$ through a trapezoidal $\mathrm{pH}$ optimal curve reflecting extremes in alkalinity and acidity. Scores of $100 \%$ were given to $\mathrm{pH}$ values ranging from 5.5 to 8.5 (fig. $5 \mathrm{a}$ ). A "less is better" curve was used to score SAR and EC. Scores begin to decrease with SAR values that exceed 7. Soil Taxonomy (1999) uses SAR greater than or equal to 13 to indicate $\mathrm{Na}$-affected soils, but other research 
Table 3. Subfactor scoring for Factor $X$, drainage class

\begin{tabular}{|l|c|}
\hline Drainage class & Score \\
\hline excessively drained and somewhat excessively drained & 85 \\
well drained & 100 \\
moderately well drained & 90 \\
somewhat poorly drained & 70 \\
poorly drained and very poorly drained & 50 \\
\hline
\end{tabular}

Table 4. Subfactor scores for Factor $X$, erosion class

\begin{tabular}{|l|c|c|}
\hline Erosion class & Lowland scores & Upland scores \\
\hline 0 & 100 & 100 \\
1 & 80 & 95 \\
2 & 60 & 85 \\
3 & 40 & 75 \\
4 & 20 & 65 \\
\hline
\end{tabular}

Note: Erosion ratings were different for uplands versus lowlands because slope is a dominant variable impacting erosion class ratings in uplands.

Figure 6. "Optimal: more is better" fuzzy rating curve for Factor $X$, depth to saturation during the growing season.

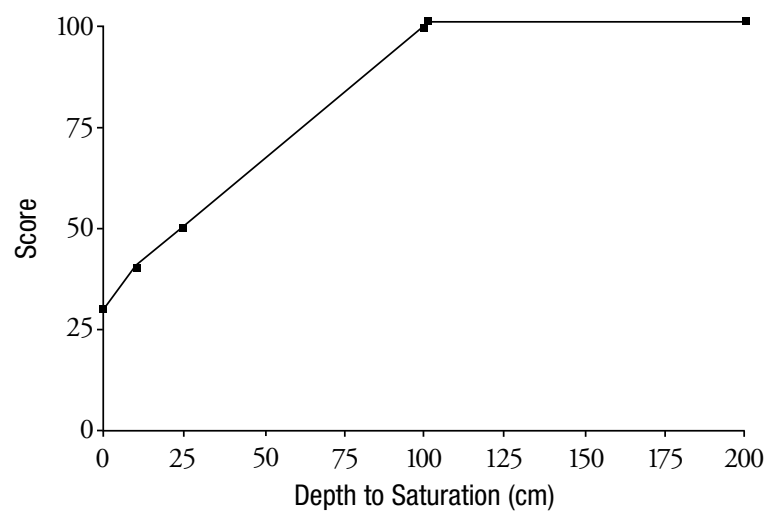

has shown that soil water movement can be affected by $\mathrm{Na}$ dispersion at SAR as low as 5 (Shainberg et al. 1981). Scores begin to decrease when EC is greater than 1 and then decrease sharply when the threshold for saline soils ( $\mathrm{EC} \geq 4 \mathrm{dSm}^{-1}$ ) is surpassed (Regional Salinity Laboratory Staff 1954) (figs. 5B and 5C).

Crisp scores were assigned to certain soil physical properties because many are interpretations reported as classes rather than measured continuous variables. Scores for drainage class and erosion class were derived using crisp values (tables 3 and 4). Scores for a particular erosion class were higher for uplands because slope is a component of the erosion class. Also, because slope was already considered in Factor C, these scores were adjusted to avoid penalizing the site twice for the same condition. Uplands versus lowlands were identified in NASIS based on landform type and scored separately.

Saturated soils, flooding frequency, and flood duration adversely affect plant growth when present during growing season. The length of the growing season was determined from the soil temperature regime. Soils with cryic, pergelic, or isofrigid temperature regimes were given the shortest growing season, July and August. Soils with frigid or mesic temperature regimes were given a growing a season from May to September, while thermic temperature regimes were given a growing season from March to October. Isomesic and hyperthermic regimes were given growing seasons that extended 11 months of the year, from February through December. Isothermic and isohyperthermic temperature regimes had year-round growing seasons.

The minimum depth to saturated conditions encountered during the growing season was derived from the fuzzy logic curve "more is better" (fig. 6). Flooding (duration and frequency) was also assessed according to these defined growing seasons.

Soil survey interpretations of flooding frequency class and flooding duration class were used to describe the impact of flood events that occur during the growing season. Flooding frequency is an estimate of the number of flood events that occur in a month. Flooding duration is the length of time flood waters reside on a particular site. Scores were established for flooding duration and frequency classes that are reported in NASIS (table 5). The scores for a particular flooding 
Table 5. Subfactor scores for Factor X, flooding frequency* and duration during the growing season

\begin{tabular}{|l|c|c|c|}
\hline $\begin{array}{l}\text { Flooding } \\
\text { frequency class }\end{array}$ & Score & $\begin{array}{c}\text { Flooding } \\
\text { duration class }\end{array}$ & Score \\
\hline none & 100 & none & 100 \\
very rare & 100 & extremely brief & 100 \\
rare & 90 & very brief & 100 \\
occasional & 85 & brief & 95 \\
frequent & 70 & long & 85 \\
very frequent & 60 & very long & 75 \\
\hline
\end{tabular}

Note: Flooding frequency and duration classes are defined in the National Soil Survey Handbook (USDA NRCS 2007).

Figure 7. Linear rating curve for flooding interaction, which was calculated using the flooding frequency and flooding duration class scores from table 5 as follows: flooding interaction $=($ frequency class $/ 100) \times($ duration class $/ 100)$.

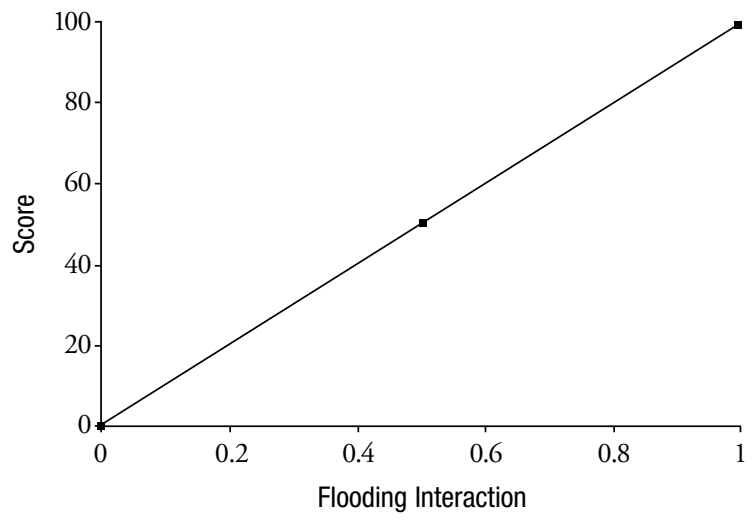

duration class and flooding frequency class were then multiplied to get a flooding frequency and duration factor for the growing season. A linear relationship was used to devise a score for this subfactor (fig. 7).

\section{Advantages of the Modeled STORIE INDEX APPROACH}

The revised Storie Index represents a significant improvement on the 1978 classification system. This NASIS-derived index is a rapid, unbiased, and accurate technique for generating potential land productivity ratings for soil survey areas. It is capable of generating hundreds of Storie ratings in seconds for SSURGO II datasets.

The NASIS model is a data-driven tool that reduces the subjectivity of the hand-generated Storie Index and improves the reliability of these ratings, which may guide land use policy for the future.

Our model deviated from Storie 1978 because of the way some soil and landscape attributes are stored in NASIS. Changes were also made to improve the objectivity of scoring. For Factor A, profile groups were condensed from nine in Storie 1978 to four because the range in scores was similar in some groups (Profile Groups I to III and VII to IX). We also eliminated Profile Group VI in Storie 1978 because of its similarity to Group IV. Multiple changes were made for Factor X, which we call the "Dynamic Factor." Instead of using alkali conditions as described in Storie 1978, our model used EC and SAR values to document saline, sodic, and salinesodic conditions. An assessment of nutrient status was not attempted in our model because fertility can be a very dynamic property in agricultural settings, depending on fertilization practices and other variables. Flooding frequency and duration of saturation during the growing season were added to Factor $\mathrm{X}$ because of their importance in assessing land capability. Microrelief was not used in our model because it is often not populated in NASIS (especially in older surveys) and because land leveling has altered most agricultural land that once contained microrelief. 
This digital soil classification scheme was designed with the intent to be modified and improved.

The revised model could be modified in many ways. For example, we developed arbitrary fuzzy rating curves for Factor A based on the scoring range from Storie 1978. As a result, the shape of the lines and slopes are not similar among profile groups, with no clear reason as to why they vary. A possible future modification would be to develop a more quantitative index to describe the rating of profile groups in Factor A based on changes in texture within the effective rooting zone. In addition, Histosols, Gelisols, Spodosols, Oxisols, and Andisols could be included in Factor A. Factor B could be modified to lower the scores of soils having rock fragment content greater than $50 \%$. Similarly, Factor C could be changed so that slopes greater than $45 \%$ are scored even lower. Including the magnesic mineralogy class for Factor X could be considered to identify nutrientlimiting conditions associated with soils derived from serpentinite or other ultramafic rock.

Future changes to the revised model can be easily accommodated in NASIS. NASIS has been updated to include the revised Storie Index for all soil survey areas in California that have SSURGO II data. The 1978 Storie ratings, interpreted manually, will also be preserved. All future soil surveys will have a Storie Index generated only through the revised, NASIS-modeled Storie Index. This information is stored in the USDA NRCS Soil Data Mart (http://soildatamart.nrcs.usda.gov/) and can also be retrieved from the USDA NRCS Web Soil Survey (http://websoilsurvey.nrcs.usda.gov) or the UC Davis California Soil Resource Lab's Online Soil Survey (http://casoilresource.lawr.ucdavis.edu).

\section{ACKNOWLEDGMENTS}

The authors thank Professor Michael J. Singer for his technical assistance, and Dave Smith, California State Soil Scientist, for his support.

\section{REFERENCES}

Cox, E. 1999. The fuzzy systems handbook. 2nd ed. San Diego: Academic Press.

O'Geen, A. T., and S. B. Southard. 2005. A revised Storie Index modeled in NASIS. Soil Survey Horizons 46(3): 98-109.

Reganold, J. P., and M. J. Singer. 1979. Defining prime farmland by three land classification systems. Journal of Soil and Water Conservation 34:172-176.

Regional Salinity Laboratory (U.S.). 1954. Diagnosis and improvement of saline and alkali soils. USDA Agriculture Handbook No. 60. Washington, DC: Government Printing Office; USDA ARS Web site, http://www.ars.usda.gov/Services/docs.htm?docid=10158.

Shainberg, I., J. D. Rhodes, and R. J. Prather. 1981. Effect of low electrolyte concentration on clay dispersion and hydraulic conductivity of a sodic soil. Soil Science Society of America Journal 45:273-277.

Storie, R. 1932. An index for rating the agricultural values of soils. Bulletin 556. Berkeley: California Agricultural Experiment Station.

—. 1978. Storie index soil rating. Oakland: University of California Division of Agricultural Sciences Special Publication 3203.

USDA NRCS (U.S. Department of Agriculture Natural Resources Conservation Service). 1999. Soil taxonomy. 2nd ed. USDA Agriculture Handbook No. 436. Washington, DC: Government Printing Office.

2007. National soil survey handbook. Title 430-VI. USDA Web site, http://soils.usda.gov/technical/handbook/. 


\section{FOR FURTHER INFORMATION}

To order or obtain ANR publications and other products, visit the ANR Communication Services online catalog at http://anrcatalog.ucdavis.edu or phone 1-800-994-8849. You can also place orders by mail or FAX, or request a printed catalog of our products from

University of California

Agriculture and Natural Resources

Communication Services

6701 San Pablo Avenue, 2nd Floor

Oakland, California 94608-1239

Telephone 1-800-994-8849

510-642-2431

FAX 510-643-5470

E-mail: danrcs@ucdavis.edu

(C2008 The Regents of the University of California Agriculture and Natural Resources

All rights reserved.

No part of this publication may be reproduced, stored in a retrieval system, or transmitted, in any form or by any means, electronic, mechanical, photocopying, recording, or otherwise, without the written permission of the publisher and the authors.

\section{Publication 8335}

ISBN-13: 978-1-60107-561-1

Page 1 photo by A.T. O'Green.

The University of California prohibits discrimination or harassment of any person on the basis of race, color, national origin, religion, sex, gender identity, pregnancy (including childbirth, and medical conditions related to pregnancy or childbirth), physical or mental disability, medical condition (cancer-related or genetic characteristics), ancestry, marital status, age, sexual orientation, citizenship, or service in the uniformed services (as defined by the Uniformed Services Employment and Reemployment Rights Act of 1994: service in the uniformed services includes membership, application for membership, performance of service, application for service, or obligation for service in the uniformed services) in any of its programs or activities.

University policy also prohibits reprisal or retaliation against any person in any of its programs or activities for making a complaint of discrimination or sexual harassment or for using or participating in the investigation or resolution process of any such complaint.

University policy is intended to be consistent with the provisions of applicable State and Federal laws.

Inquiries regarding the University's nondiscrimination policies may be directed to the Affirmative Action/ Equal Opportunity Director, University of California, Agriculture and Natural Resources, 1111 Franklin

Street, $6^{\text {th }}$ Floor, Oakland, CA 94607, (510) 987-0096. For information about ordering this publication, telephone 1-800-994-8849. For assistance in downloading this publication, telephone 530-754-3927.

An electronic copy of this publication can be found at the ANR Communication Services catalog Web site, http://anrcatalog.ucdavis.edu.

\section{UCER}

REVIEWED This publication has been anonymously peer reviewed for technical accuracy by University of California scientists and other qualified professionals. This review process was managed by the ANR Associate Editor for Land, Air, and Water Sciences. xm-pr-9/08-SB/RW 